\title{
Main Concepts in Pragma Linguistic Analysis of Literary Text (In the Examples of Gafur Gulyam's Works)
}

\author{
Nozima Kozakova \\ Scientific Research Worker of NamSU, Namangan, Uzbekistan
}

\begin{abstract}
In this article we intend to analyze principles, categories and main concepts of text in pragmalinguistic analysis, pragmalinguistic potential of literary text and personality factor's place and significance in it.
\end{abstract}

Keywords: Pragmalinguistics, literary text, comparative analysis, lexical, grammatical and stylistic systems, metaphors, discursive markers

\section{Introduction}

Pragmalinguistic analysis of text, issues of category and main concepts of analyses in this direction have been studied by T. Van Deyk, Aznaurova, V. A. Maslova in world linguistics, as well as by M. Hakimov, A. Ko'chiboyev, S. Boymirzayeva, S. Qurbonova in Uzbek linguistics. Literary text is a complex linguistic object of studies with many features. Because, it consists of variouslexical, grammatical and stylistic systems - systems within systems. Literary text appears on the basis of dialectic unity of creativity, knowledge, creation,emphasizing [13.9] Literary text realization of human beings surrounding through language. It is a form of personalities self- realization. [2.4.]

\section{Materials and Methods}

In the article comparative, pragmalinguistic methods of analysis have been used.

\section{Results of the research and their Discussion}

Literary text is result of literary understanding of reality and its expression it is formulated on the basis of authors aim idea system of creativity, it also fully demonstrate pragmatic opportunities, vocabulary expressive tools of language. Expressionsbecome the main point of such text with harmony of form in substance.In sourcesregarding text linguistics it is indicated that linguistic studiesof poetic and prosaic literary text are halt based on analyses of language spaces' units. In linguistic analyses literary text main attention is paid to such issues as significance of language expression tools in text structure, types of literary speech, styles, metaphors, literary work's vocabulary. The above mentioned common features also exist in pragmalinguistic analysis of literary text. However object of studies in pragmalinguistics is analyzed not only by language spaces' unit, but also based on principles main concept of verbal dialog. If linguopoetic, stylistic and lexical-semantic approach to literary text pays more attention to formal elements and enables to discover language'sfeatures by expressive tools,pragmaticalanalysis using language elementshelps us to study heroes' inner world, pragmatic possibilities of language, author's attitude towards time and reality. It is of huge significance for pragmalinguistic analysis to identify how every verbal expression is used, what aim it serves, linguistic features of verbal act,and pragmatic features of authors and characters' speech. Consequently, the term pragmatics of literary text means a complex of an author's aims directed at wide interpretation of language tools by a reader, directed at influencing a reader by speech of characters.[7.8.]

The concept of personality has become one of the main concepts in modern linguistics. A range of approaches related to anthropocentric paradigm, which analyze linguistic problems in connection with personality, have emerged. As professor N. Makhmudov writes about this paradigm: "In accordance with a languages' such objective feature a human being takes centralplace in anthropocentric paradigm as language is considered as main element formulating human's personality. Specialists refer to famous Russian author S. Dovlatov's maxim "ninety present of a human's personality consist of a language". As V. A. Maslova puts it one cannot imagine a human being's wisdom without his/her personality, ability to create speech, and understanding a language. [5.56]

Famous linguist V.V.Bogdanov defines humane factors as the following:

1) Language qualification, that is, interaction of communicants through the knowledge of a language code;

2) National origins;

3) Social, cultural status (social origins, profession, position, cultural standards and habits, education degree, living place, family status);

4) Biological-physiological information (gender, age, health, presence or absence of disabilities);

5) Psychological type (temperament, introvert or extrovert, elements of pathology);

6) Current psychological situation (mood, current knowledge, aim and interests);

7) Degree of communicants' acquaintance;

8) This establishedtaste interests and habit;

9) External view (clothing, manners and etc.).

The above-mentioned signs have great significance in different societies. Hence, they have various use in verbal 


\section{International Journal of Science and Research (IJSR) \\ ISSN: 2319-7064}

ResearchGate Impact Factor (2018): 0.28 | SJIF (2018): 7.426

dialogue, however, in general, they are all considered as signs which have communicative importance. [4.9]

In pragmalinguistic analyses of literary text huge attention is paid to human factor personalities of an author, a hero and a reader are considered as pragmalinguistic categories. In fact a human being is the main focus and the object of art and literature. [1.32] People with different characters became generalized under common features and included in to a literary work. On the spaces individual speech types are created. It demands unique skills from an author to use a word in harmony with heroes' inner world situation and narratives in accordance with the literary aim. Literary work's pragmatic opportunities depend on an author's style, harmony of heroes' speech with a situation.

Literary text shows not only literary qualification of an author, but also demonstrated his/her linguistic skills. Major representative of XX century Uzbek literature, famous writer, philosopher poet GafurGulyam's prose demonstrated languages pragmatic possibilities aesthetic functions influential strength in colorful verbal expressions the authorizes such works as "Disobedient", "Yodgor", "My pure thief kid" are written in a brilliant way not only from literary perspective, but also from linguistic point or view. Especially "Disobedient" novel and "My pure thief kid" short story are designed with a language very similar to folk language. This feature churlserved for success of the works. Light humor gives attractions situations described in this works positive mood to heroes and strengths to their personalities. "Pure and sincere laughter is a whip beating spiritual-moral disadvantages. Finding a funny aspect of sum barrier and laughing at it is specially over coming this barrier", as writes P. Kodirov. [3.83] We observeexactly this situation in G. Gulyams "Disobedient" novel. Despite main character's poor family conditions, his orphanage, his loses a reader does not feel negative attitude towards him, but gets filled with sympathy, encouragement, not giving up in life's conflicts.

"Disobedient's" speech is full ofmetaphors, discursive markers with life verbal colors, appellative units, forms of verbal mixtures "different names, nicknamescharacterizing words disclosure the main feature of the work-server as a tool for expressing its humoristic nature".[11.67]

From a literary work's point of view author and a reader, a character and a reader, a character and a character verbally interact with each other. In the proses of formulating a literary text and author's views ideological intensions strategy of creating works text, choice of linguistic tools have an uttermost significance. All verbal expressions related to a personality, his||her inner spiritual conditions, individual style of speechesofferideashis\|her intention of how to express an idea are considered as an object of pragmatic studies. In this primed emotionalattitudearises from the spiritual conditions of a text's author. The private attitudeof an author is sometimes implicitly/explicitly. [15.34.39] In some works there is a narrator's speech, an author's defined ideological intentions, use positive or negative evaluation of an object of description time and reality are included in that narrative. In particular, events in "Disobedient", "Yodgor" novels, "My pure thief kid", "Salesmen", "A man" short stories are narrated via a character's speech. In "Disobedient's" speech we observe sentences and phrases typical for fourteen year old boy and on that basis we see the authors own views. For instance: For little youngsters likes wondering in market one of the funny moments for killing time werestreet idiots. During those times there were so many idiots in Tashkent that one would not be able to count them of: Malla idiot, Mayramxon, Holparang idiot, Tojihon, Dauble dove, Olim idiot, Eshonoyi, Avaz idiot and others...Every idiot had his// her own specifics capris "sweetness". (G. Gulyam "Disobedient") Author this every idiot's habits or described in a funny way and reasons behind there is mental desire or also given. In this exact moments we can observe the author's use. As prominent scholarD. Quronov puts it: In overview a reader is provided with an opportunity to look at the reality of the novel through the prism of two perspectives: we can conclude that funny the tales are told by a teenager narrator tragic throws about those pure people are told by the author himself. In other worlds looking through of a teenager the writer analyses the reality and tragic to the roots of the tragedy.[14.41]

E.Soboleva, who analyzed pragmalinguistic features literary texts in English says that pragmatic aspect of an author's speech is incorporated into delivering the social evaluationattitude of an author towards events. She says that pragmatics of an author's speech consists of informative emotional-evaluative and literary-stylistic features. Indeed, while describing time an object an event a character in all parts of a literary work: exposition, developmentof the events, culmination, scenery, portrait an author fulfilsintentions aimed at providing a static spiritual gain for a reader via literary description metaphorical thinking, emotional evaluation and information.For instance: In the middle of a large pond there was a clay cobbled hut like a piece of nutshell, barely standing like an old horse, it was propped up from four sides and the old gate was covered, there was lightof a pale, shimmering candle which can be seen vaguely from a wicket covered with a paper instead of a pane. A rattling singing voice was coming out of the hut. (G. Gulyam "Hasan Kayfiy"). The writer mentions that it was taken from folklore humorous tales after the title. In the fragment above, the main purpose of the author is to inform the story of the hero's life and social status, and to create a humorous image by first comparing the hut to a piece of a nutshell and then an old horse. Most importantly, in the last sentence singing of the hero which was added in order to indicate that the state of the hut does not have a negative impact on the heroic state brings tolerance and excitement towards him.

In addition to the author's speeches in the literary text, the heroic speeches can also be the object of a particular pragmalinguistic analysis. Master writers do not use much narration; instead they describe their characters as lifelike, lively, revealing their humanity through their heroes' words. This process is implementedvia dialogue. Especially dialogue is of great important in the composition of the prose. "The dialogue develops very closely knitted with the author's narration. It plays an important role in the composition of the narrative and cannotexistapart from the speech system."[10,3] A dialogue describes the spiritual

\section{Volume 8 Issue 5, May 2019 www.ijsr.net}




\section{International Journal of Science and Research (IJSR) \\ ISSN: 2319-7064}

ResearchGate Impact Factor (2018): 0.28 | SJIF (2018): 7.426

condition of heroes and their relationships, reveals their attitude to the describedsituations and various speech situations appear. E. Soboleva points out that the dialogue of personalities can be divided into the following components:

- Emotional - evaluative lexical (reference, zoometahphors, superlative adjectives, phrases;prosodic elements (punctuation helps the reader to understand the content quickly and accurately);

- Methodical features and characteristics of the speech (peculiarities of heroic speech);

Informativeness;

The impact of socio - cultural factors (discrimination in society, social background, gender and age, type of communication, etc.);

The psychological basis of dialogue (building relations between the participants of the dialogue ...) $[9,55-56]$

Specific features of discourse are distinct in the dialogues of a literary text. Evidently, discourse is considered to be one of the basic concepts of pragmalinguistics, A. Nurmanov assesses the discourse as a phenomenon reflecting a person's subjective spirit, and inserts it into the study of pragmatism $[6,197]$ while Sh. Safarovdescribes it as maximum unit of linguisticlevel, a speech tool which is systematically arranged by its communicative function and adapted to the condition of the conversation, as well as indicates the text as a type of it. [8] Comparing the text and the discourse phenomena, he proposes studying these two phenomena in terms of "hypernym" and "hyponym". [8,]

Discourse is a communication process which consists of correspondence of linguistic and non-linguistic units reflecting social, cultural, ethnic, psychological, emotionalexpressive value, and communicative-pragmatic-linguistic phenomenon, demonstrating the relationship between a speaker and a listener, speech situations and communicative strategies of the person who delivers the speech. These features are fully realized in dialogues from the point of view of artistic text. Dialog is not just chat which consists of heroic exchange of ideas, but a phenomenon that is of great structural importance in the plot and composition of the narration, which reflects the position and outlook of the heroes and creates a positive or negative evaluation of a reader.

The understanding process of literary texts and conversational communication is significant. Speech perception (hearing and learning) includes the following stages:

- Accessing to an internal speech code with an acoustic or graphic code;

- Understanding syntactic structures and grammatical forms (deciphering);

- Understanding the general plan of the statement;

- To understand the theme and idea of the statement;

- Evaluating the received information (evaluation of content, idea and author's position);

- Understanding the choice of language units and forms $[4,35]$
When above-mentioned stages are successfully implemented, as well as the processes of expressing ideas and understanding are repeated appropriately, then communication between speaker and listener or writer and reader is considered to be implemented effectively.

In conclusion, it can be said that the pragmatic and logical study of literary texts enables the development of speech communication models, scientific analysis of linguistic competence and mechanisms of selection of methods and means of contributing, thinking and understanding processes.

In conclusion, it can be said that studying the literary text from pragmalinguistic point of view allows us to develop speech models, to analyze linguistic competence, selection mechanisms of its providing methods and tools, and to study the processes of thinking and understanding.

\section{References}

[1] Бобоев Т. Адабиётшунослик асослари. - Тошкент: Ўзбекистон, 2002.

[2] Ёқубов И. Бадиий матн ва эстетик талқин. Тошкент: Фан ва технология нашриёти, 2013.

[3] Каримова Ю. Маънавий - ахлоқий мавзунинг юмористик талқини./Ўзббек тили ва адабиёти, 2016.№5. Б. $83-85$.

[4] Маслова А. Введение в прагмалингвистику. Москва: Флинта, Наука, 2010.

[5] Махмудов Н. Тил тилсими тадқиқи. - Тошкент: Мумтоз сўз, 2017.

[6] Нурмонов А. Танланган асарлар. -Тошкент: Академнашр, 2012. 3-жилд.

[7] Почепцов Г. Прагматика текста. - Калинин, 1980.

[8] Сафаров Ш. Прагмалингвистика. -Тошкент, 2008.

[9] Соболева Е. Проблемы прагматики англоязычного художественного текста.// Известия ПГПУ, № 6, 2008. С. $55-56$.

[10]Солижонов Й. Диалог қурилиши ва унинг элементлари.// Ўзбек тили ва адабиёти, 2010. №3. Б.3-7

[11]Улуқов Н. “Шум бола” қиссасидаги библионим ва антропонимлар хусусида. //Ўзбек тили ва адабиёти, 2017. №3. Б. 66-69.

[12] Ўринбоев Б., Кўнғуров Р., Лапасов Ж. Бадиий текстнинг лингвистик тахлили. - Тошкент, Ўқитувчи, 1990.

[13]Қиличев Э. Матннинг лингвистик тахлили. Бухоро: Бухоро университети, 2000.

[14] Қуронов Д. Кулги зимнидаги жиддият.// Мутолаа ва идрок машқлари. - Тошкент: Академнашр, 2013.

[15] Хакимов М. Илмий матнда хусусий муносабат масалаларига доир. // Ўзбек тили ва адабиёти. 1992. №3. Б. 34-39. 